\title{
The Development of the Russian Legal System after the "Accession" of the Republic of Crimea to the Russian Federation
}

\section{Introduction}

On 18 March 2014, the Agreement between the Russian Federation and the Republic of Crimea on the Accession of the Republic of Crimea to the Russian Federation and on Forming New Constituent Entities within the Russian Federation was signed. ${ }^{1}$ Almost all other countries and international organizations described this step as illegal annexation. ${ }^{2}$ Regardless of how this situation is treated by international law, we are faced with a fait accompli and the word "accession" will be used in this article. The Republic of Crimea became a federal subject of the Russian Federation and Russian law will govern all its legal relations.

Therefore, the Ukrainian legal system that governed in Crimea had to be replaced by the Russian one. So, after the "accession" Ukrainian law ceased to apply. The main transition period was set by the Russian Federation, with the end on 1 January 2015. Until that date, the normative legal acts adopted by the Autonomous Republic of Crimea and by Sevastopol, a city with special status, were binding in the Republic of Crimea, unless they were contrary to the Constitution of the Russian Federation. Russian laws and normative legal acts were also applicable in that period.

The main aim of this article is to analyse how legal regulations worked during the transition period. Changes in the law directly influenced the residents of the territory of the Republic of Crimea, who found themselves to be in a situation that can be described as a 'legal vacuum.'The Ukrainian and Russian legal systems grew out of Soviet legisla-

1 Dogovor mezhdu Rossiiskoi Federatsiei i Respublikoi Krym o prinyatii w Rossiiskuyu Federatsiyu Respubliki Krym i obrazovanii v sostave Rossiiskoi Federatsii novykh sub'ektov (podpisan v g. Moskve 18.03.2014), http://www.garant.ru/hotlaw/federal/531718/ [access: 16.02.2017].

2 P. Grzebyk, Aneksja Krymu przez Rosję w świetle prawa międzynarodowego, "Sprawy Międzynarodowe" 2014, no.1, pp.19-37; J. Kranz, Kilka uwag na tle aneksji Krymu przez Rosje, "Państwo i Prawo" 2014, no. 8, pp. 23-40. 
tion. Nevertheless, during the independent development of the two countries, both legal systems accumulated some differences in the approaches to various legal institutions. Residents of Crimea nowadays have to conclude legal transactions that under a legal system which is unfamiliar to them. In addition, the transition period was characterised by the fact that the law was created on a day-to-day basis, which means that legal certainty became merely imaginary, while legal certainty in the contemporary world has become one of the basic requirements for the whole of society and the individuals' quality of life. ${ }^{3}$

The article starts with an analysis of the legal background to the accession of Crimea to the Russian Federation, then examines whether the accession documents are in accordance with Russian law. The Russian legal system includes laws which define the procedures for the admission of other states to the Russian Federation. Analysis of the accession documents and Russian laws indicates that during the Crimean accession events were artificially created in an attempt to ensure their compliance with Russian legislation. The next part of the article describes changes in Russian civil law, criminal law, commercial law and tax law. The main transition period was set to end on 1 January 2015 by the Russian legislator. During its implementation, however, it became clear that this was not sufficient, and in some fields it was prolonged. In some fields the new legislation turned out to be more favorable, while in some regulations were more stringent for Crimean residents than the Ukrainian ones. The third part of the article will provide an analysis of changes in the Judiciary within the transition period. This was the most problematic issue for the Crimean residents. The lack of qualified lawyers was the biggest challenge. The last part of the article provides a summary and offers conclusions

\section{The accession of the Republic of Crimea to the Russian Federation}

\section{The legal background to the accession}

On 17 March 2014, the Republic of the Crimea proclaimed itself an independent and sovereign state, with Sevastopol as a city with special status. ${ }^{4}$ That decision was taken on the basis of the results of the Crimean referendum and the Declaration of Independence of Crimea. On 6 March 2014, the Presidium of the Supreme Council of Crimea adopted Resolution nr 1702-6/14 "On holding the Crimean referendum." According to this document, the referendum would be held on 16 March 2014. There were two choices offered:

3 Cf. M. Wojciechowski, Pewność prawa, Gdańsk 2014.

4 Postanovlenie Verkhovnoi Rady Respubliki Krym 'O nezavisimosti Kryma,' 'Sbornik normativno-pravovykh aktov Respubliki Krym” 2014, no. 3, part 1, pp. 64-65.

5 Postanovlenie Verkhovnoi Rady ARK 'O provedenii obshchekrymskogo referenduma,'ibidem, pp. 11-12. 
1. Do you support the reunification of Crimea with Russia with all the rights of the federal subject of the Russian Federation?

2. Do you support the restoration of the Constitution of the Republic of Crimea in 1992 and the status of Crimea as part of Ukraine?

On 17 March the official results of the referendum were published. 1,274,096 people who were entitled to vote in the referendum took part (83.10\%). 1,233,002 people answered the first question positively (96.77\%), while 31,997 answered the second question affirmatively (2.51\%).

Just before the referendum, on 11 March, the Supreme Council of Crimea and the Sevastopol City Council adopted the "Declaration on the independence of the Autonomous Republic of Crimea and the city of Sevastopol."6 In accordance with the provisions of this document, if a decision to become part of Russia was made in the Referendum of 16 March 2014, Crimea, including the Autonomous Republic of Crimea and the city of Sevastopol, would be proclaimed an independent and sovereign state with a republican order. After the referendum results were announced, the Supreme Council of Crimea adopted the resolution 'On the independence of Crimea.' In that document Crimea was proclaimed an independent sovereign state as the Republic of Crimea, and the city of Sevastopol was given a special status within it. At the same time, the Supreme Council of the Autonomous Republic of Crimea on behalf of the Republic of Crimea requested that the Russian Federation accept the Republic of Crimea as a new constituent entity of the Russian Federation with the status of a republic.

On the same day, 17 March, the President of the Russian Federation signed the executive order on the recognition of the Republic of Crimea as a sovereign and independent state. ${ }^{7}$ The next day, President Putin notified the Federation Council of the Federal Assembly, the State Duma of the Federal Assembly and the Government, of proposals by the State Council of the Republic of Crimea - the Parliament of the Republic of Crimea and the Legislative Assembly of the city of Sevastopol regarding the accession of the Republic of Crimea, including the city of Sevastopol, to the Russian Federation and the formation of new constituent territories within the Russian Federation. Such action was taken pursuant to Article 6 of the Federal Constitutional Law "On the Procedure of Admission to the Russian Federation and the Formation Within It of New Constituent Territories." Additonally, on 18 March 2014 the Agreement between the Russian Federation and the Republic of Crimea on the Accession of the Republic of

6 Deklaratsiya nezavisimosti Avtonomnoi Respubliki Krym i goroda Sevastopolya, ibidem, pp. 185-186.

7 Ukaz Prezidenta Rossiiskoi Federatsii ot 17 marta 2014 g. N 147 'O priznanii Respubliki Krym,' http://base.garant.ru/70613384/ [access: 16.02.2017].

8 Federalnyi konstitutsionnyi zakon Rossiiskoi Federatsii ot 17.12.2001, no. 6-FKZ 'O poryadke prinyatiya v Rossiiskuyu Federatsiyu i obrazovaniya v ee sostave novogo sub'ekta Rossiiskoi Federatsii,' http://base.garant.ru/184002/ [access: 16.02.2017]. 
Crimea to the Russian Federation and on Forming New Constituent Entities within the Russian Federation (Agreement) was signed by the President of the Russian Federation, the Chairman of the State Council of the Republic of Crimea, the Prime Minister of the Republic of Crimea and the Chairman of the Coordinating Council for the establishment of the Sevastopol municipal administration. According to the Agreement, the Republic of Crimea is considered to have acceded to the Russian Federation from the date of the Agreement's signing. Beginning on the day that the Republic of Crimea acceded to the Russian Federation, two new constituent entities were formed within the Russian Federation: the Republic of Crimea and the Federal City of Sevastopol. This document included provisions concerning the "accession" of the Republic of Crimea to the Russian Federation and the formation of new constituent entities within the Russian Federation, including provisions regarding the territories of the new Russian constituent entities, their residents' citizenship, and the constituent entities' government bodies. The Agreement was applied provisionally from the date of signature and had to enter into force on the date of ratification.

The State Duma and the Federation Council ratified the Agreement on 20 and 21 March, respectively. The Federal Constitutional Law "On Accession to the Russian Federation the Republic of Crimea and Establishing within the Russian Federation new constituent entities of the Republic of Crimea and the City of Federal Importance Sevastopol” (FCL) was also adopted. ${ }^{9}$ President Putin immediately signed both documents: FCL and the Federal Law "On Ratifying the Agreement between the Russian Federation and the Republic of Crimea on the Accession of the Republic of Crimea in the Russian Federation and on Forming New Constituent Entities within the Russian Federation." ${ }^{10}$ According to Article 3 of the FCL, Crimea's admission to the Russian Federation was considered retroactive, as of $18 \mathrm{March}$.

The unprecedented speed of the adoption and implementation of the decisions concerning this issue must be noted. On 6 March 2014 the decision was taken by the Crimean authorities regarding the referendum that would be held on 16 March 2014, and on 21 March the Russian parliament concluded the process of Crimea's accession to the Russian Federation. No one doubted the outcome of the Crimean referendum, which was also swiftly announced the very next day - 17 March. But the rapid pace of the accession of Crimea and Sevastopol to the Russian Federation was even more

9 Federalnyi konstitutsionnyi zakon ot 21.03.2014, no. 6-FKZ 'O prinyatii v Rossiiskuyu Federatsiyu Respubliki Krym i obrazovanii v sostave Rossiiskoi Federatsii novykh sub'ektov - Respubliki Krym i goroda federalnogo znacheniya Sevastopolya,' http://base.garant.ru/184002/ [access: 16.02.2017].

10 Federalnyi zakon ot 21.03.2014, no. 36-FZ 'O ratifikatsii Dogovora mezhdu Rossiiskoj Federatsiei i Respublikoi Krym i obrazovanii v sostave Rossiiskoi Federatsii novykh subektov', http://base.garant.ru/70618344/ [access: 16.02.2017]. 
amazing: the State Duma and the Federation Council both took their decisions within 2 days. This was truly breakneck speed for such a significant act, one which changed the borders of two countries. It seems that members of the Russian parliament simply followed the motto "why we should discuss, if we agree with everything." The whole situation was summed up by senator Lyskov at the meeting of the Federation Council which was dedicated to President Putin's request to use military force in Ukraine: “[...] we are wasting the president's time."11

\section{Accession and Russian law}

Russian legislation provides clauses for the incorporation of a foreign state or part of one into the Russian Federation. Such a possibility is foreseen under Art. 65 of the Constitution of the Russian Federation and the federal law enacted pursuant to the Constitution "On the Procedure of Admission to the Russian Federation and the Formation Within It of New Constituent Territories". Although that law had been in existence for a long time (from 2001), it had never been used previously. ${ }^{12}$

According to Article 4.2 of the law, "The admission to the Russian Federation as a new entity of a foreign country or its part is carried out by mutual agreement of the Russian Federation and of the foreign state in accordance with international agreement on the admission to the Russian Federation as a new entity of a foreign country or its part [...], signed by the Russian Federation with the foreign country."

The law also provides the following procedure for the admission of the new entity to the Russian Federation: the foreign state takes the initiative for accession to the Russian Federation of the foreign state or its part; the President of the Russian Federation notifies the State Duma and the Federation Council about this initiative; the Russian Federation and a foreign country sign an international agreement; following the signing of such an agreement the President of the Russian Federation appeals to the Constitutional Court with a request to verify the compliance of the agreement with the Constitution of the Russian Federation; and if the Constitutional Court confirms the compliance, the agreement in question is submitted to the Federal Assembly for ratification, together with a draft federal constitutional law on the admission to the Russian Federation of the new entity.

Following the above description, the actions taken by the Russian authorities were, at least formally, compliant with the federal legislation in question. After the agreement was signed, the President of the Russian Federation sent the requisite request to the Constitutional Court. The Court issued its decision on 19 March, in which it recognised

11 Stenograma trista sorok sed'mogo (vneocherednogo) zasedaniya Soveta Federatsii 1 marta 2014 goda, Federalnoe Sobranie Rossiiskoi Federatsii, Iskh. St-347 ot 0103.2014, Moskva, p. 26.

12 P. Romashov, Poryadok prinyatiya v sostav Rossiiskoi Federatsii novogo sub'ekta RF, "Probely v rossiiskom zakonodatelstve" 2014, no. 2, p. 26. 
the Agreement between the Russian Federation and the Republic of Crimea as compliant with the Constitution of the Russian Federation. The Court stated that it only decided on questions of law and did not assess the political advisability of an international treaty of the Russian Federation. So from the legal and formal point of view of the Russian Federation, the accession of Crimea to the Russian Federation was in accordance with Russian law.

However, several questions arise that cannot be overlooked here. First, the Russian President signed the executive order on the recognition of the Republic of Crimea as a sovereign and independent state, referring to the outcome of the referendum. But according to the results of this referendum, Crimea should be part of Russia, which is incompatible with the status of a "sovereign and independent state." The issue of state independence was not even put to a vote during the Crimean referendum. Second, the Constitutional Court's decision was taken immediately, without public debate and hearing other views. Such proceedings were even criticised by Russian lawyers. According to a former employee of the Constitutional Court, professor Kryazhkov, "consideration of the case took place in a procedure unknown to the Law on Constitutional Court of the Russian Federation."13

Furthermore, as was mentioned above, according to Russian law a foreign state takes the initiative for accession to the Russian Federation and this particular foreign state has to sign an accession agreement. Therefore, in order to comply with this order, and with Crimea being an integral part of the state of Ukraine, an initiative of this foreign state, i.e. an initiative by Ukraine, would be required. However, the Russian Federation sticks to the position that after the referendum outcome the Republic of Crimea became an independent state, and as such it was recognised by Russia, so an international agreement was signed with the state known as the Republic of Crimea. This is a disputable position since, as was mentioned, the questions raised in the referendum did not refer to the issue of independence, but only of joining Russia.

It thus appears that during the Crimean accession process the sequence of events, and the events themselves, were artificially created in an attempt to ensure their compliance with the Russian legislation.

\section{Changes in the Russian law after the "accession" of the Republic of Crimea to the Russian Federation}

The "accession" of one state to another state has implications both in international law and in domestic law. In international law it is connected with concept of 'succession.' It

13 V. Kryazhkov, Krymskii pretsedent: konstitutsionno-pravovoe osmyslenie, "Sravnitel'noe konstitutsionnoe obozrenie" 2014, no. 5, p. 87. 
is "the replacement of one State by another in the responsibility for the international relations of territory." ${ }^{14}$ In other words, it involves the transfer of the territory of one state to another state. The issue of succession is well known and is beyond the scope of this article. ${ }^{15}$ In domestic law, a change of the state's sovereignty over the territory leads to a change in the law in a given territory. In history such cases have occurred repeatedly. A recent example is provided by the unification of the Federal Republic of Germany and the German Democratic Republic. The legal framework for this unification was established in "The Unification Treaty between the FRG and the GDR." 16 In the field of the harmonization of law, the general rule was to extend federal law to the 'accessed' territory with simultaneous continuous of validity of the GDR law as long as it was compatible with federal law.

In turn, according to Art. 6 of the Agreement, "from the day that the Republic of Crimea accedes to the Russian Federation and new constituent entities are formed and until January 1, 2015, a transition period is in effect for setting issues of integrating the new federal constituent entities into the Russian's Federation economic, financial, credit and legal systems, Russia's system of government agencies, and implementation issues of military duty and military service in the territories of the Republic of Crimea and the Federal City of Sevastopol." Article 6 ("Transition period") of the FCL contains a similar provision.

The transition period was characterised by the adoption of a great number of regulations to govern the relations in Crimea, especially by the Russian Federation. The changes affected all aspects of Crimean society. Unfortunately, presentation of all these changes is not possible within the scope of this publication and only certain changes made by the Russian legislator to the previously existing legislation - aimed at integration of Crimea to the Russian legal system - will be presented further.

\section{Civil law}

The most important changes to the Civil Code of the Russian Federation caused by the accession of the Republic of Crimea were introduced by the Federal Law "On Amendments to the Federal Law 'On implementation of the Part One of the Civil Code of the

14 Vienna Convention on the Succession of States in Respect of Treaties from 23 August 1978, United Nations, “Treaty Series”1978, vol. 1946, p. 3.

15 Cf. D. P. O'Conell, State Succession in Municipal and International Law, London 1967; M. Mrak, Succession of States, The Hague 1999; R. Szafarz, Sukcesja państw w odniesieniu do traktatów we wspótczesnym prawie międzynarodowym, Wrocław 1982.

16 The Unification Treaty between the FRG and the GDR from 31 August 1990, German Unification and Its Discontents. Documents from the Peaceful Revolution; United States of America, ed. R. T. Gray, S. Wilke, Minneapolis 1996, pp. 258-265. 
Russian Federation' and to Article 1202 of Part Three of the Civil Code of the Russian Federation." ${ }^{" 17}$

This law implemented the mechanism of re-registration for legal entities of the Republic of Crimea, which had been registered according to Ukrainian legislation. Thus, according to this law, a legal entity that wanted to acquire the right to re-register to the legal entity of the Russian Federation needed to provide its founding documents by January 1, 2015, in compliance with the legislation of the Russian Federation and to apply for their data entry into the Unified State Register of Legal Entities.

A necessary condition for obtaining this right to re-register is the permanent executive body or, in the absence of a permanent executive body, a body or person authorised to act on behalf of the legal entity without a power of attorney being located in the territory of the Republic of Crimea or the federal city of Sevastopol on the date of the accession of Crimea to Russia.

According to the amendments to art. 1202 of the Civil Code of Russia, the personal law of a legal entity shall be deemed the law of the country where the legal entity has been founded, unless otherwise provided by the Federal Law "On Amendments to the Federal Law 'On implementation of the Part One of the Civil Code of the Russian Federation' and to art. 1202 of Part Three of the Civil Code of the Russian Federation."This implies that with the acquisition of the status of being a legal entity of the Russian Federation, legal entities registered under Ukrainian law in the territory of the Autonomous Republic of Crimea would automatically be considered as legal entities of the Republic of Crimea and therefore as subjects of the Russian Federation. Legal entities, which did not bring their founding documents by 1 January 2015, in compliance with the legislation of the Russian Federation, and did not apply for their data entry into the Unified State Register of Legal Entities, are obliged to acquire the status of a branch of a foreign entity. We should mention that the process of re-registration of legal entities was free of charge till 2015.

At the end of the year, on 31 December 2014, the Federal Law "On Amendments to the Article 19 of the Federal Law 'On implementation of the Part One of the Civil Code of the Russian Federation" was adopted, which extended the transition period for changing the status of a Ukrainian legal entity to a Russian legal entity. ${ }^{18}$ According to this law, Crimean legal entities had time to re-register until 1 March 2015, as well as legal entities that decided to acquire the status of a branch of a foreign entity. Legal entities

17 Federalny zakon ot 5.05.2014, no. 124-FZ "O vnesenii izmenenii v federalnyi zakon 'O vvedenie v deistvie chasti pervoi Grazhdanskogo kodeksa Rossiiskoi Federatsii’ i stat'yu 1202 chasti tret'ei Grazhdanskogo kodeksa Rossiiskoi Federatsii,"' http://base.garant.ru/70648870/ [access: 16.02.2017].

18 Federalny zakon ot 31.12.2014, no. 506-FZ "O vnesenie izmenenii v stat'yu 19 Federalnogo zakona 'O vvedenie v deistvie chasti pervoi Grazhdanskogo kodeksa Rossiiskoi Federatsii," http://www.consultant.ru/document/cons_doc_LAW_173197/ [access: 16.02.2017]. 
that did not bring their founding documents in compliance with the legislation of the Russian Federation, did not apply for their data entry into the Unified State Register of Legal Entities, and did not acquire the status of a branch of a foreign entiry within the specified time, had no right to operate on the territory of the Russian Federation and were subject to liquidation. Agricultural farms had time to re-register to 1 July 2015.

The extension of the transition period for re-registering was granted due to the fact that a small number of existing organizations re-registered by the required deadline of 1 January 2015. According to the Federal Tax Service, as of 12 September 2014 1,166 entities had already re-registered in conformity with the legislation of the Russian Federation..$^{19}$ As of 6 February 2015 there were 13,944 entities re-registered. ${ }^{20}$ However, there were about 29,000 legal entities registered in Crimea before 18 March 2014. ${ }^{21}$ So, approximately half of the enterprises located in the territory of the Republic of Crimea had been re-registered by February 2015.

In the opinion of the deputies of the City Council of Crimea, re-registration was not been completed in time due to delays in the registration authorities' processing times. In connection with this, entrepreneurs did not have enough time to obtain new registration documents. ${ }^{22}$ But this is just one of the reasons. In addition, the legislation of Ukraine establishes the specific legal forms of legal entities that do not exist in Russian legislation. In Russia there are no such forms as, for example, private enterprises and associations of co-owners of apartment buildings. According to Art. 113 of the Economic Code of Ukraine, private enterprise is deemed an enterprise that acts on the basis of private ownership of one or more citizens of Ukraine, foreigners, stateless persons and his/her/ their labor or with the use of employed labor. An enterprise is also deemed private if it acts on the basis of private ownership of a business entity - a legal entity. It is most similar to the Russian limited liability company (LLC). The main feature of an LLC is the procedure of the charter capital formation. In contrast to an LLC, an enterprise

19 Svedeniya o yuridicheskikh litsakh, sozdannykh na territoriyakh Respubliki Krym i g. Sevastopolya do 18 marta 2014 g., svedeniya o kotorokh vneseny v EGRYUL v svyazi s privedeniem imi svoikh uchreditelnykh dokumentov $\mathrm{v}$ sootvetstvie $\mathrm{s}$ zakonodatelstvom Rossiiskoi Federatsii, 12 September 2014, http://regforum.ru/files/677_pereregistrirovannye_organizacii_ kryma_i_sevastopolya/get/ [access: 16.02.2017].

20 Svedeniya o yuridicheskikh litsakh, sozdannykh na territoriyakh Respubliki Krym i g. Sevastopolya do 18 marta 2014 g., svedeniya o kotorokh vneseny v EGRYUL v svyazi s privedeniem imi svoikh uchreditelnykh dokumentov v sootvetstvie s zakonodatelstvom Rossiiskoi Federatsii, 6 February 2015, http://www.nalog.ru/rn77/taxation/krim_sev/reg_krim/ [access: 16.02.2017].

21 Kil'kist' aktivnikh pidpriemstv za regionami Ukraini ta vidami ekonomichnoi diyal'nosti, 15 November 2013, http://www.ukrstat.gov.ua/operativ/operativ2014/kap/kap_u/kap_u13.htm [access: 16.02.2017].

22 V. Nikoforov, Krymskii biznes ne uspevaet pereiti v Rossiyu. Gossovet Kryma predlozhil prodlit' pereregistratsiyu yuridicheskikh lits, 23 November 2014, http://www.kommersant.ru/doc/2595496 [access: 16.02.2017]. 
is created on the basis of indivisible authorised capital and unlimited liability for the obligations of the company with all the founders' property. This implies that the form of an LLC is more advantageous in terms of capital protection for the founders. However, private enterprises could conduct business without a stamp and without opening a bank account, which was very convenient for many entrepreneurs. In turn, the association of the co-owners of apartment buildings is an organizational and legal form wherein the owners possess and use the property of apartment buildings, as well as manage them. In Russia, similar forms are the house-building cooperatives and houseowners' associations stipulated by Art. 110 of the Housing Code of the Russian Federation, to which it was necessary to re-register the specified entities. While the first form (private enterprise) was widespread in Ukraine, but associations of co-owners of apartment buildings were not very popular. In Crimea the number of such associations as of 31 December 2014 amounted to 1345 houses, when the multi-family housing stock of the Republic of Crimea consisted of 15069 apartment buildings. ${ }^{23}$ There were lots of difficulties with the re-registrations of joint stock companies. In Ukraine, there are two forms of joint stock companies (JSC): public and private. They needed to be re-registered into similar Russian entities. To register a JSC in Russia, the company had to conduct a general meeting of shareholders, who had to approve the transfer of the company to be under Russian jurisdiction. If some shareholders blocked the re-registration, the company would have to buy out their shares, which could be a financial burden for the enterprise. Agricultural farms also have had problems with re-registrations. Under the Russian law, they are not legal entities. But according to Ukrainian law, agricultural farms are legal entities and they keep property and land on the balance sheet. At this moment there are difficulties for them with the transition to the Russian legal field.

In turn, the Minister of Economic Development of the Republic of Crimea, Nicholas Koryazhkin, explained the small amount of re-registered entities in the following way: "issues of taxation in Ukraine are more favorable and more attractive with respect to the transition to the Tax Code of the Russian Federation." ${ }^{24}$

Finally, at the end of the transition period for changing the status of a Ukrainian legal entity to a Russian legal entity, on 1 July 2015,16,123 entities were re-registered in conformity with the legislation of the Russian Federation..$^{25}$

23 Doklad Glavy Respubliki Krym, Predsedatelya Soveta ministrov Respubliki Krym Aksenova Sergeya Valer'evicha o fakticheski dostignutykh znacheniyakh pokazatelej dlya otsenki effektivnosti deyatelsnosti organov ispolnitelnoj vlasti Respubliki Krym za 2014 god i ich planiruemykh znacheniyakh na 3-letnij period (2015), http://rk.gov.ru/rus/opendata [access: 16.02.2017].

24 V Krymu po zakonodatelstou Rossii zaregistrirovalos' 22\% SKHD, 12 November 2014, http:// investigator.org.ua/news/141573/ [access: 16.02.2017].

25 Svedeniya o yuridicheskikh litsakh, sozdannykh na territoriyakh Respubliki Krym i g. Sevastopolya do 18 marta 2014 g., svedeniya o kotorokh vneseny v EGRYUL v svyazi s privedeniem 


\section{Tax law}

According to Art. 15 of the FCL, the legislation of the Russian Federation on taxes and duties apply in the territory of the Republic of Crimea and City of Federal Importance Sevastopol from 1 January 2015.

Tax issues had to be regulated in that territory according to the legal order that was valid on 17 March 2014. But on 11 April 2014, the State Council of the Republic of Crimea adopted the resolution "Instruction On Specifics of Application of Tax Legislation and Taxes in the Republic of Crimea During the Transition Period" that amended VAT regulations. ${ }^{26}$ According to this document, the basic VAT rate was 20\% until 1 May 2014, and on 1 May 2014 the Russian rate of 18\% replaced it. It was also provided that Russian tax legislation - except for the provisions governing relations for the establishment, administration and collection of land tax and state tax collection - would be applicable to legal entities and individual entrepreneurs which had been re-registered in the Russian State Register.

It is worth noting that that the tax rate established by that Resolution was further modified by the Resolution of the State Council of the Republic of Crimea on 30 April 2014. ${ }^{27}$ Thus, the VAT rate was reduced from 1 May 2014 in the Republic of Crimea from $18 \%$ to $10 \%$. Such a low VAT rate is characteristic only for offshore areas; but in this case it was necessary first of all to attract Russian businesses and investment to Crimea, since a reduction in VAT is the most important benefit for business development and attracting investors.

Besides that, on 29 November 2014 the Federal Law "On the development of the Crimean Federal District and the free economic zone on the territory of the Republic of Crimea and the federal city of Sevastopol"28 was adopted, which was a further step taken to attract investors to Crimea. Analysis of this law indicates that of all the free economic zones of the Russian Federation, the most favorable conditions are provided

imi svoikh uchreditelnykh dokumentov v sootvetstvie s zakonodatelstvom Rossiiskoi Federatsii, 10 February 2017, https://www.nalog.ru/rn77/taxation/reg_krim/ [access: 16.02.2017].

26 Postanovlenie Gosudarstvennogo Soveta Respubliki Krym ot 11.04.2014, no. 2010-6/14 'Polozhenie ob osobennostyakh primeneniya zakonodatelstva o nalogakh i sborakh na territorii Respubliki Krym v perekhodnyi period,' 'Sbornik normativno-pravovykh aktov Respubliki Krym” 2014, no. 4, part 2, pp. 128-132.

27 Postanovlenie Gosudarstvennogo Soveta Respubliki Krym ot 30.04.2014, no. 2093-6/14 'O vnesenie izmenenii' v Postanovlenie Gosudarstvennogo Soveta Respubliki Krym ot 11.04.2014, no. 2010-6/14 'Ob utverzhdenii Polozheniya ob osobennostyakh primeneniya zakonodatelstva o nalogakh i sborakh na territorii Respubliki Krym w perekhodnyi period,' ibidem, no. 4, part 3, pp. 204-210.

28 Federalnyi zakon ot 29.11.2014, no.377-FZ `O razvitii Krymskogo federalnogo okruga i svobodnoi ekonomicheskoi zony na territoriyakh Respubliki Krym i goroda federalnogo znacheniya Sevastopolya,' http://ivo.garant.ru/\#/document/70807520/paragraph/1:1 [access: 16.02.2017]. 
in Crimea. ${ }^{29}$ In order to become a member of the Crimean zone, the investment threshold of 3.000.000 RUB is set for small and medium-sized businesses, while for large businesses it is 30.000.000 RUB. This threshold is exceptionally low for the Russian Federation. For comparison, in the special economic zone in the Kalinigrad region the minimum size of capital investments is set at 150.000 .000 RUB. ${ }^{30} \mathrm{~A}$ legal entity has to be registered in Crimea to become the member of the free economic zone. Three types of benefits are provided for investors - tax, customs and administrative.

Tax benefits include a reduced rate on corporate profit tax (part of which is paid to the federal budget - $0 \%$, to the budgets of the Republic of Crimea and Sevastopol - not more than 13.5\%), exemption from payment of property tax by members of the free economic zone (for 10 years after the registration of the property acquired for the purpose of conducting relevant activities) and land tax (for 3 years) and a reduced rate of insurance payments: Pension Fund - 6\%, Social Insurance Fund -1.5\%, Compulsory Medical Insurance Fund $-0.1 \%$. In comparison, the general tax rates in Russia are the following: the Pension Fund payment is $22 \%$, payment to the Social Insurance Fund $-2.9 \%$, medical insurance $-5.1 \%^{31}$; corporate profit tax - the part paid to the federal budget $-2 \%$, to budgets of the federal subjects $-18 \%{ }^{32}$ Customs benefits, including duty-free import to Crimea of goods, components and equipment required for the implementation of investment projects, are provided by the regime of the free customs zone.

In theory, preferential treatment should attract Russian investments to Crimea. On the other hand, it is possible that many investors will take a wait-and-see approach to the new law, because reality does not always meet business expectations. We should not forget that the economic situation in Crimea is difficult: international land routes are limited, there is no developed banking sector and there are problems with the power and water supply. It is more likely that at the beginning of its existence the free economic zone will be attractive mostly for Crimean domestic producers.

29 Informatsiya o l'gotakh, deistvuyushchikh na territotii osobykh ekonomicheskikh zon v Rossiiskoi Federatsii, http://economy.gov.ru/minec/activity/sections/sez/becomeinvestor/ news/201505194\# [access: 16.02.2017].

30 Federalnyi zakon ot 10.01.2006, no.16-FZ 'Ob osoboj ekonomicheskoi zone v Kaliningradskoi oblasti i o vnesenii izmenenii v nekotorye zakonodatelnye akty Rossiiskoi Federatsii,' http:// www.consultant.ru/document/cons_doc_LAW_57687/ [access: 16.02.2017].

31 Federalnyi zakon ot 24.07.2009, no. 212-FZ 'O strakhovykh vznosakh v Pensionnyi fond Rossiiskoi Federatsii, Fond sotsialnogo strakhovaniya Rossiiskoi Federatsii, Federalnyi fond obyazatelnogo meditsinskogo strakhovaniya i territorialnye fondy obyazatelnogo meditsinskogo strakhovaniya,' http://www.consultant.ru/document/cons_doc_LAW_89925/[access: 16.02.2017].

32 Nalogovyi kodeks Rossiiskoi Federatsii. Chast vtoraya, http://base.garant.ru/10900200/ [access: 16.02.2017]. 


\section{Licensed activities}

The regulation of licensed activities by Russian legislation is a very important issue for those entrepreneurs and legal entities in Crimea dealing with licensed products or services. Generally, in Russia it is much more difficult to obtain licenses for licensed activities than in Ukraine.

Article 12 of FCL guaranteed that during the transition period business permits (licenses, except licenses to conduct banking operations and licenses (permits) for the activities of non-credit financial institutions) in the Republic of Crimea and Sevastopol, issued by the state and other authorities of Ukraine, the government and other official bodies of the Autonomous Republic of Crimea, the state and other authorities of the city of Sevastopol, will be valid without limitation of their validity period and any confirmation by the public authorities of the Russian Federation, the Republic of Crimea and the federal city of Sevastopol.

Originally it was planned that Crimean companies would start working with the Russian licenses from 1 January 2015. Most of the difficulties were caused by the Russian norms concerning issuance of licenses for the sale of alcohol. According to the Federal law 'On the state regulation of production and turnover of ethyl alcohol, alcohol and alcohol products and limitation of consumption (drinking) of alcohol production,' only legal entities can sell alcohol. ${ }^{33}$ Private entrepreneurs can only sell alcohol products such as beer and cider. In addition, in order to obtain a license, one needs to provide a rental agreement for at least a year or an ownership document for stationary commercial property of a certain square footage. Besides a rental agreement or a property ownership document, a certificate from the Unified State Register of Rights to Real Estate is also needed.

Taking into account the fact that not all legal entities have been re-registered and there have been problems with obtaining a certificate from the Unified State Register of Rights to Real Estate, a decision was made to significantly simplify the licensing procedure for the sale of alcohol by Crimean companies. On 31 December 2014 a Federal Law was adopted: "On Amendments to the Federal law 'On state regulation of production and turnover of ethyl alcohol, alcohol and alcohol products and limitation of consumption (drinking) of alcohol production." ${ }^{34}$ This law made it easier for sellers of alcoholic beverages established prior to 2015 to obtain licenses, as they were not required to

33 Federalnyi zakon ot 22.11.1995, no. 171-FZ 'O gosudarstvennom regulirovanii proizvodstva i oborota etilovogo spirta, alkogolnoi i spirtosoderzhashchei produktsii i ob ogranichenii potrebleniya (raspitiya) alkogolnoi produktsii,' http://base.garant.ru/10105489/ [access: 16.02.2017].

34 Federalnyi zakon ot 31.12.2014, no. 491-FZ "O vnesenii izmenenii v Federalnyi zakon 'O gosudarstvennom regulirovanii proizvodstva i oborota etilovogo spirta, alkogolnoi i spirtosoderzhashchei produktsii i ob ogranichenii potrebleniya (raspitiya) alkogolnoi produktsii," http:// www.consultant.ru/document/cons_doc_LAW_173117/ [access: 16.02.2017]. 
possess a commercial property of a certain square footage. The requirement for the lease of commercial property, which had to exceed one year was also abolished, which made it possible to not register a rental agreement in the Unified State Register of Rights to Real Estate. Individual entrepreneurs engaged in the retail sale of beer in Crimea are relieved from the requirement to have stationary retail facilities. ${ }^{35}$ Those amendments should have a positive impact on the preservation of economic stability on the peninsula and help to prevent the growth of counterfeiting and illegal trade of alcoholic beverages.

It should be noted that, in accordance with current legislation, the Ukrainian licenses that had not expired were still valid. So, legal entities which did not re-register, were entitled to sell alcoholic beverages until 1 March 2015. As was mentioned, the process of re-registering was extended to this date.

It was also decided to extend the time for obtaining the Russian licenses. Consequently, on December 292014 the Federal Constitutional Law was adopted: "On Amendments to the Article 4 and the Article 12 of the Federal Constitutional Law 'On Accession to the Russian Federation the Republic of Crimea and Establishing within the Russian Federation the new constituent entities of the Republic of Crimea and the City of Federal Importance Sevastopol." ${ }^{36}$ Article 12 was changed, and according to this, the deadline for obtaining the Russian licenses was set for 1 June 2015. Until that date, all business activities were divided into two categories - under a compulsory license under Russian law, and without obtaining a license - by using the notification procedure. The notification procedure is supposed to be used for the delivery of medical services, the decontamination and disposal of waste, the conservation of cultural inheritance and development, and the production, testing and repair of aircrafts. This procedure will apply until 1 January 2018. Also until 1 January 2018 there is a moratorium on planned inspections of companies operating in less risky areas for the community and state - where the planned inspections are carried out once every three years.

\section{Criminal law}

Criminal law is the subject of Article 9.20 of the FCL. It is provided that the investigation of criminal cases which were pending before the bodies of preliminary investigation operating in the Republic of Crimea on the day of 18 March 2014 should be carried out

35 According to the Federal Law "On the basis state regulation of commercial activities in the Russian Federation," stationary retail facilities are commercial properties, which are a building or part of a building, the foundation of which is firmly connected with land and connected toa network of engineering and technical support.

36 Federalnyi konstitutsionnyi zakon ot 29.12.2014, no. 19-FKZ “O vnesenii izmenenii v stat' $\mathrm{i}$ 4 i 12 Federalnogo konstitutsionnogo zakona 'O prinyatii v Rossiiskuyu Federatsiyu Respubliki Krym i obrazovaniya v sostave Rossiiskoi Federatsii novykh sub'ektov - Respubliki Krym i goroda federalnogo znacheniya Sevastopolya," http://base.garant.ru/70830620/ [access: 16.02.2017]. 
according to the criminal procedural legislation of the Russian Federation. Criminal cases were submitted for examination to courts on condition that the accusation was supported by the Prosecutor of the territorial authority of the Prosecutor's Office of the Russian Federation on behalf of the Russian Federation.

On 5 May 2014, the Federal Law "On the Application of Provisions of the Criminal code of the Russian Federation and the Code of Penal Procedure of the Russian Federation in the territories of the Republic of Crimea and the Federal City of Sevastopol" was adopted. ${ }^{37}$ It was approved that Russian criminal law applies to criminal cases in Crimea and Sevastopol that date back to the period before 18 March 2014. Application of more stringent penalties for crimes committed prior to 18 March 2014 is not allowed. This means that a more severe penalty than the one that had to be applied at the time of the crime can not be imposed, i.e. when the Criminal Code of the Russian Federation stipulates a tougher penalty or considers an action as a crime, while the Criminal Code of Ukraine does not - this law cannot be applicable to suspects and defendants.

The law defines the mode of action with evidence in support of pre-trial proceedings that was not completed by 18 March 2014. ${ }^{38}$ The prosecutor has the main role in that process. The prosecutor determines the type of prosecution and investigative jurisdiction in accordance with the Criminal Procedure Code of the Russian Federation. The prosecutor should decide if acts containing elements of crime are crimes under Russian law or not.

The above-mentioned law also stipulates how cases examined before 18 March 2014 will be treated. Judgments of the Ukrainian courts on the territory of the Republic of Crimea and Sevastopol before March 18 have the same legal force as judgments of the Russian courts. There is a possibility to appeal against judgments issued before $18 \mathrm{March}$ 2014. However, this has to be done in compliance with Russian law.

None of these documents stipulated that the legislation of the Republic of Ukraine in Crimea continued to apply during the transition period. This raises the question about the possibility of local law enforcement officers applying the criminal and criminal procedural law of the Russian Federation in Crimea. Criminal cases that were investigated under the Criminal Procedure Code of Ukraine were formed on the basis of other legislation, which is qualitatively different from the Russian Criminal Procedure Code. ${ }^{39}$

37 Federalnyi zakon ot 5.05.2014, no. 91-FZ..., op. cit.

38 E. Kremyanskaya, A short note of the development of the Criminal Justice System after the Accession of Crimea and Sevastopol to the Russian Federation, "New Journal of European Criminal Law" 2014, vol. 5, no. 2, pp. 258-259.

39 Cf. E. Alontseva, Sledstvennye deistviya po ugolovo-protsessual'nomu zakonodatel'stvu RF i Ukrainy (sravnitelno-pravovoe issledovanie), "Mezhdunarodnoe ugolovnoe pravo i mezhdunarodnaya yustitsiya” 2010, no. 2, pp.17-19; N. Kovtun, Sudebnye stadii i proizvodstva UPK Ukrainy: sistema $i$ vektory realizovannykh normativnykh reform, "Ugolovnoe sudoproizvodstvo" 2013, no. 2, pp. 23-30; I. Makeeva, Ponyatie dosudebnogo proizvodstva po ugolovno-protsessual'nomu 
Despite this, the investigation should continue in accordance with the criminal procedure legislation of the Russian Federation. At the same time, law enforcement employees have not studied criminal law and criminal procedure legislation of the Russian Federation before. The current legal situation can trigger unpredictable consequences. A criminal case for organizing and participating in mass riots on 26 February 2014 could be a good example of such case. In January - February 2015 three Crimean Tatars were arrested in the course of a criminal investigation into the organization and participation in mass riots on 26 February 2014 (Article 212.1 and 2 of the Criminal Code of the Russian Federation). At that time the arrested suspects were citizens of Ukraine and Crimea was Ukrainian territory. According to Article 12.3 of the Criminal Code of the Russian Federation, criminal proceedings against foreign nationals who have committed crime on the territory of another State is possible only for a crime against the interests of the Russian Federation or a citizen of the Russian Federation. The question is what this investigation is trying to prove: that in February 2014 Ukrainian citizens in Crimea committed acts against the interests of Russia or its citizens?

\section{The judiciary in the transition period in the Republic of Crimea and Sevastopol}

According to Article 9 of the FCL, during the transition period in the Republic of Crimea and Sevastopol courts of the Russian Federation (the federal courts) were created in accordance with the legislation of the Russian Federation on the judicial system.

Civil, administrative and commercial cases, as well as criminal cases, admitted to the proceedings of courts of first instance, operating in the territory of the Republic of Crimea and Sevastopol, prior to 18 March 2014 and which had not been decided by that time continue to be considered in accordance with the relevant legislation of the Russian Federation. Criminal cases will be considered on condition that the accusation will be supported by the prosecutor of the relevant territorial authority of the Russian Federation Prosecutor's Office on behalf of the Russian Federation.

Immediately after this law came into force, the Crimean courts temporarily ceased to adjudicate, although claims that were based on the norms of Russian legislation were accepted. However, in practice, the judicial system in Crimea has remained almost wholly inactive. The reason for this collapse was the collision of the legal systems of two different states. Such dualism in the legal regulation of various aspects of social relations has created severe difficulties in resolving a number of issues. Despite the genetic relatedness of the procedural legislation of the Russian Federation and Ukraine, there are

zakonodatel'stvu Rossiiskoi Federatsii i Ukrainy, "Mezhdunarodnoe ugolovnoe pravo i mezhdunarodnaya yustitsiya” 2013, no. 5, pp. 9-13. 
nevertheless a number of differences, from the procedure for determining the amount of the state's court costs, the procedure for notifying participants in the process and collecting evidence, through to the issuance of the writ of execution. ${ }^{40}$ For example, in accordance with the Law of Ukraine "On the judicial assembly," the court fee is charged as a rate of the minimum monthly wage established by law as of January 1 of the calendar year, in which the relevant application or complaint is filed to court - in relation to the amount of the claim and as a fixed amount. The amount of the court fees for filing a court claim of a property nature depends on the type of court. In a court of general jurisdiction the amount of the court fee is 1 percent of the amount of the claim but not more than 3 times the minimum wage, in the commercial court $-2 \%$ of the amount of the claim but not exceeding 60 minimum wages, in the administrative court $-2 \%$ of the amount of the claim but not more than 4 minimum wages. ${ }^{41}$ In Russia, the amount and payment procedure of state fees (including court costs) is established by the Tax Code of the Russian Federation. In a court of general jurisdiction the amount of the court fee is dependent on the amount of the claim. The minimal amount of the court fee is $4 \%$ of the amount of the claim but not less than 400 RUB. The maximum amount of the court fee is charged when the amount of the claim of more than 1.000.000 RUB and is 13,200 RUB + 0,5\% of the amount exceeding 1.000.000 RUB, but not more than 60000 RUB. Obviously, from the claimant's point of view, the method set out in the Ukrainian legislation was more favorable.

Furthermore, according to Article 9.5 of the FCL, "persons holding positions of judges in courts (in Crimea on the day of its accession to the Russian Federation), shall continue to administer justice to the creation and launching of the courts of the Russian Federation in these territories if they have Russian citizenship." During the first months after Crimea's accession to the Russian Federation not so many people obtained Russian citizenship. Hence, there were situations whereby citizens of Ukraine had to make judicial decisions on behalf of Russia. The judges working in Crimean courts generally do not have an appropriate knowledge of Russian law. Thus the peculiar situation arose whereby a person who was a citizen of one country and had not lost or given up their citizenship and was appointed by the previous governing state to a specific position and given the required oath, suddenly - without being released from these positions either an his own request or for other reasons - began to serve the interests of another State that had not even nominated him or her to that position. Realizing the inconsistency of this situation, which was not governed by relevant legislation, and given the absence of

40 N. Marysheva, Regulirovanie mezhdunarodnogo grazhdanskogo protsessa v stranakh SNG, in Mezhdunarodnoe chastnoe pravo, ed. N. Marysheva, Moskva 2011, pp. 836-844.

41 Zakon Ukrainy N 3674-VI ot 8.07.2011 'O Sudebnom Sbore,' http://kodeksy.com.ua/ka/o_ sudebnom_sbore.htm [access: 16.02.2017]. 
their own knowledge and skills, the judges tried not to make any decisions and simply delayed trials. As was pointed in an interview of the Chairman of the Economic Court of the Republic of Crimea Sergey Lazarev, the consideration of cases that had started in accordance with Ukrainian legislation were suspended, because the judges who stayed to work in Crimea had no right to consider cases before a decision on their obtaining Russian citizenship. ${ }^{42}$

In order to resolve this situation, on June 23, 2014 the President of the Russian Federation signed a number of federal laws aimed at the formation of the judicial system of the Republic of Crimea and Sevastopol:

- The Federal Law "On the Creation of Courts of the Russian Federation in the Republic of Crimea and the City of Federal Importance Sevastopol and on Amending to Some Legislative Acts of Russian Federation," 43

- The Federal Law "On the Bodies of the Judicial Community of the Republic of Crimea and the City of Federal Importance Sevastopol,"44

- The Federal Law "On the procedure of selection of candidates for the initial composition of the federal courts, established in the territory of the Republic of Crimea and the City of Federal Importance Sevastopol," ${ }^{5}$

- The Federal Constitutional Law "On creation of the Twenty First Arbitration Appeal Court, and on Amending the Federal Constitutional Law 'On arbitration courts in the Russian Federation."'46

The Federal Law "On the Creation of Courts of the Russian Federation in the Republic of Crimea and the Federal City of Sevastopol" provides for the establishment of the Supreme Court of the Republic of Crimea, the Arbitration Court of the Republic of Crimea, twenty four district and city courts of the Republic of Crimea; and the Arbitra-

42 M. Bludshaya, Okkuporovannoe pravosudie v Krymu i "litsa, zamschayuschie dolzhnosti sudei," 28 March 2014, http://racurs.ua/496-okkupirovannoe-pravosudie-v-krymu-i-lica-zameschauschie-doljnosti-sudey [access: 16.02.2017].

43 Federal'nyi zakon ot 23.06.2014, no. 154-FZ 'O sozdanii sudov Rossiiskoi Federatsii na territoriyakh Respubliki Krym i goroda federalnogo znacheniya Sevastopolya i o wnesenii izmenenii v otdel'nye zakonodatel'nye akty Rossiiskoi Federatsii,' http://ivo.garant.ru/\#/document/70681114/paragraph/1:1 [access: 16.02.2017].

44 Federal'nyi zakon ot 23.06.2014, no. 155-FZ 'Ob organakh sudeiskogo soobscchestva Respubliki Krym i goroda federal'nogo znacheniya Sevastopolya,' http://www.consultant.ru/document/cons_doc_LAW_164497/ [access: 16.02.2017].

45 Federal'nyi zakon ot 23.06.2014, no. 156-FZ 'O poryadke otbora kandidatov v pervonachal'nye sostavy federal'nykh sudov, sozdavaemykh na territiriyakh Respubliki Krym i goroda federal'nogo znacheniya Sevastopolya,' http://www.consultant.ru/document/cons_doc_LAW_ 164494/ [access: 16.02.2017].

46 Federal'nyi Konsitutsionnyi zakon ot 23.06.2014, no. 10-FKZ "O sozdanii dvadtsat' pervogo arbitrazhnogo apellyatsionnogo suda i o vnesenii izmenenii $\mathrm{v}$ federal'nyi konstitutsionnyi zakon 'b arbitrazhnykh sudakh v Rossiiskoi Federatsi," http://www.consultant.ru/document/ cons_doc_LAW_164495/ [access: 16.02.2017]. 
tion Court of Sevastopol, the Sevastopol City Court, four district courts of Sevastopol, the Crimean Military Court and the Sevastopol Military Court. The law also establishes rules for considering cases and submitting for examination to the general, commercial, appellate commercial, administrative, appellate administrative courts operating in the territory of the Republic of Crimea and Sevastopol, and those not resolved on $18 \mathrm{March}$ 2014. The law confirms the provisions of Article 20.4 of the FCL - the resolution about the day in which the activities of the courts were to start in Crimea had to be made at the Plenum of the Supreme Court of the Russian Federation. The courts of the Russian Federation officially only started their activities on 26 December 2014 in accordance with the resolution of the Plenum of the Supreme Court, which was only adopted on 23 December 2014. ${ }^{47}$

The Federal Law "On the procedure of selection of candidates for the initial composition of the federal courts, established in the territory of the Republic of Crimea and Sevastopol city of federal significance" establishes the procedure for selecting judges. This selection is made on a competitive basis, taking into consideration the legal education, professional experience and the results of the admittance examination. This law established a preferential right for individuals holding the position of judge in courts operating in the territory of the Republic of Crimea and Sevastopol on 18 March 2014 to fill the positions of judge of the federal courts of general jurisdiction and arbitration courts, if they acquired Russian citizenship and complied with the requirements for candidates for the post of judge in accordance with Russian federal law. For such individuals, the law establishes an exception. In such a case, a basic document confirming the existence of a foreign nationality (passport), together with a disclaimer of it, must be transferred to the Judicial Department of the Supreme Court of the Russian Federation. In accordance with the legislation of Ukraine, the date of renunciation of citizenship is the date of publication of a relevant decree of the President of Ukraine. Thus in practice it was possible that active judges of Russian Federation would officially be citizens of Ukraine as well. Accordingly, the transfer of their Ukrainian passport together with a letter of resignation of their Ukrainian citizenship was supposed to serve, according to the Russian legislators, as a certain guarantee of the intention of such persons to resolve the situation with their citizenship.

Completion of the formation of the judiciary of the Republic of Crimea and Sevastopol occurred before 1 July 2015. After that date, the further formation and operation of the judiciary has been carried out in the usual manner, in accordance with the procedure adopted in Russia.

47 Postanovlenie Plenuma Verkhovnogo Suda RF 'O dne nachala deyatel'nosti federal'nykh sudov na territoriyakh Respubliki Krym i goroda federal'nogo znacheniya Sevastopolya,' http:// supcourt.ru/search.php?searchf=\%EA\%F0\%FB\%EC [access: 16.02.2017]. 


\section{Conclusion}

The accession of Crimea to the Russian Federation is a complicated process of extending the Russian legal system to the territory of the Republic of Crimea. The Russian and Ukrainian legal systems have many differences, in all fields. Residents of Crimea were not familiar with Russian law, which additionally was changing during the transition period. At the same time, residents of the new Russian federal entity are not always sufficiently aware and prepared for the fact that Russian and the Ukrainian laws are quite different. Furthermore, professionals whose task is to apply the law - judges and the employees of judicial authorities - faced the same problem. Residents of Crimea had to re-register companies initially registered according to the Ukrainian legislation. That time was extended. During that time more than half of the existing companies registered before 18 March 2014 were re-registered. The remaining companies ceased their activity. Currently the main challenge for Crimean entrepreneurs is to conduct business according to Russian legislation. The decision to impose a moratorium on the planned state audits of certain types of company should surely be welcomed. However, it would be advisable to introduce a temporary moratorium on the application of penalties in relation to Crimean entrepreneurs for violations identified during the first state audit. Many questions are arising in connection with criminal law; lack of legal competence within the employees of the judicial authorities remains the biggest problem. The transition period was characterised by discrepancies, difficulties and lack of clarity in the judiciary. From 1 July 2015 the judiciary has carried out its duties in accordance with the procedure followed in Russia. Unfortunately, there is evidence that violations of the Federal law of the Russian Federation in the Republic of Crimea are frequently committed by courts of the first instance. ${ }^{48}$ One of the ways to improve the quality of the judiciary may be sending Russian judges to work in Crimea. This solution was adopted during the harmonisation of the judiciary after the unification of RFN and GDR.

It was necessary to ensure that the residents of the Republic of Crimea had legal certainty, which has become one of the basic criteria for the whole of society and the individuals' quality of life in the contemporary world. As was mentioned, the principle of legal certainty is one of the most important of the European democratic achievements. It makes the actions of both state authorities and citizens more predictable. Unfortunately, during the transition period Russian legislature has failed to set conditions for the legal certainty of Crimean residents in all fields of life. However, the legal integration of Crimea to the Russian Federation has started and seems irrevocable. For the successful continuation of this integration, it is necessary to improve the qualifications of the

48 V. Kululaev, Zakonodatelstvo Rossii ne rabotaet v Krymu, 19 August 2015, http://7x7-journal.ru/ post/66107 [access: 16.02.2017]. 
employees of the judicial authorities, as well as the legal awareness and legal culture of Crimean society.

\section{Literature}

Alontseva E., Sledstvennye deistriya po ugolovo-protsessual'nomu zakonodatel'stou $R F$ i Ukrainy (sravnitelno-pravovoe issledovanie), "Mezhdunarodnoe ugolovnoe pravo i mezhdunarodnaya yustitsiya" 2010, no. 2 .

Bludshaya M., Okkuporovannoe pravosudie v Krymu $i$ "litsa, zamschayuschie dolzhnosti sudei," 28 March 2014, http://racurs.ua/496-okkupirovannoe-pravosudie-v-krymu-ilica-zameschauschie-doljnosti-sudey [access: 16.02.2017].

German Unification and Its Discontents. Documents from the Peaceful Revolution, ed. R.T. Gray, S. Wilke, Washington 1996.

Grzebyk P., Aneksja Krymu przez Rosje w swietle prawa międzynarodowego, "Sprawy Międzynarodowe" 2014, no. 1.

Kovtun N., Sudebnye stadii i proizvodstva UPK Ukrainy: sistema i vektory realizovannykh normationykh reform, "Ugolovnoe sudoproizvodstvo" 2013, no. 2.

Kranz J., Kilka uwag na tle aneksji Krymu przez Rosje, "Państwo i Prawo" 2014, no. 8.

Kremyanskaya E., A short note of the development of the Criminal Justice System after the Accession of Crimea and Sevastopol to the Russian Federation, "New Journal of European Criminal Law” 2014, vol. 5, no. 2.

Kryazhkov V., Krymskii pretsedent: konstitutsionno-pravovoe osmyslenie, "Sravnitel'noe konstitutsionnoe obozrenie" 2014, no. 5.

Kululaev K., Zakonodatelstvo Rossii ne rabotaet v Krymu, 19 August 2015, http://7x7-journal.ru/post/66107 [access: 16.02.2017].

Makeeva I., Ponyatie dosudebnogo proizvodstva po ugolovno-protsessual'nomu zakonodatel'stou Rossiiskoi Federatsii i Ukrainy, "Mezhdunarodnoe ugolovnoe pravo i mezhdunarodnaya yustitsiya” 2013, no. 5 .

Markin V., V Krymu zaderzhan odni iz liderov obschestvennoi organizatsii "Medzhlis krymsko-tatarskogo naroda" po podozreniyu v organizatsii i uchastii v massovykh bespriadkach, 29 January 2015, http://sledcom.ru/news/item/889047/ [access: 16.02.2017].

Marysheva N., Regulirovanie mezhdunarodnogo grazhdanskogo protsessa v stranakh SNG, in Mezhdunarodnoe chastnoe pravo, ed. N. Marysheva, Moskva 2011.

Mrak M., Succession of States, The Hague 1999.

Nikoforov V., Krymskii biznes ne uspevaet pereiti v Rossiyu. Gossovet Kryma predlozbil prodlit' pereregistratsiyu yuridicheskikh lits, 23 November 2014, http://www.kommersant.ru/doc/2595496 [access: 16.02.2017].

O'Conell D. P., State Succession in Municpal and International Law, London 1967. 
Romashov P., Poryadok prinyatiya v sostav Rossiiskoi Federatsii novogo sub'ekta RF, "Probely v rossiiskom zakonodatelstve" 2014, no. 2 .

Szafarz R., Sukcesja państw w odniesieniu do traktatów we wspótczesnym prawie międzynarodowym, Wrocław 1982.

V Krymu po zakonodatelstvu Rossii zaregistrirovalos' 22\% SKHD, 12 November 2014, http://investigator.org.ua/news/141573/ [access: 16.02.2017].

Vienna Convention on the Succession of States in Respect of Treaties, 1978.

Wojciechowski M., Pewnośc prawa, Gdańsk 2014.

Deklaratsiya nezavisimosti Avtonomnoi Respubliki Krym i goroda Sevastopolya, “Sbornik normativno-pravovykh aktov Respubliki Krym” 2014, no. 3, part 1.

Postanovlenie Gosudarstvennogo Soveta Respubliki Krym ot 11.04.2014, no. 2010-6/14 'Polozhenie ob osobennostyakh primeneniya zakonodatelstva o nalogakh i sborakh na territorii Respubliki Krym v perekhodnyi period,' 'Sbornik normativno-pravovykh aktov Respubliki Krym”2014, no. 4, part 2.

Postanovlenie Gosudarstvennogo Soveta Respubliki Krym ot 30.04.2014, no. 2093-6/14 'O vnesenie izmenenii' v Postanovlenie Gosudarstvennogo Soveta Respubliki Krym ot 11.04.2014, no. 2010-6/14 'Ob utverzhdenii Polozheniya ob osobennostyakh primeneniya zakonodatelstva o nalogakh i sborakh na territorii Respubliki Krym w perekhodnyi period,' ibidem, no. 4, part 3.

Postanovlenie Verkhovnoi Rady ARK 'O provedenii obshchekrymskogo referenduma,' “Sbornik normativno-pravovykh aktov Respubliki Krym” 2014, no. 3, part 1.

Postanovlenie Plenuma Verkhovnogo Suda RF 'O dne nachala deyatel'nosti federal'nykh sudov na territoriyakh Respubliki Krym i goroda federal'nogo znacheniya Sevastopolya,' http://supcourt.ru/search.php?searchf=\%EA\%F0\%FB\%EC [access: 16.02.2017]. Postanovlenie Verkhovnoi Rady Respubliki Krym 'O nezavisimosti Kryma,' "Sbornik normativno-pravovykh aktov Respubliki Krym” 2014, no. 3, part 1.

Stenograma trista sorok sed'mogo (vneocherednogo) zasedaniya Soveta Federatsii 1 marta 2014 goda, Federalnoe Sobranie Rossiiskoi Federatsii, Iskh. St-347 ot 0103.2014, Moskva.

Ukaz Prezidenta Rossiiskoi Federatsii ot 17 marta 2014 g. N 147 ‘O priznanii Respubliki Krym,' http://base.garant.ru/70613384/ [access: 16.02.2017].

Zakon Ukrainy N 3674-VI ot 8.07.2011 'O Sudebnom Sbore,' http://kodeksy.com.ua/ $\mathrm{ka} /$ o_sudebnom_sbore.htm [access: 16.02.2017]. 


\section{SUMMARY \\ The Development of the Russian Legal System after the "Accession" of the Republic of Crimea to the Russian Federation}

On March 18 2014, the Republic of Crimea became a federal subject of the Russian Federation and the Ukrainian legal system was changed to the Russian system. The transition period was set to end on January 12015 . This transition period was characterized by the fact that the law was created on a day-to-day basis, and as the residents of Crimea were unfamiliar with Russian law they found themselves in a legal vacuum. Laws were adopted in an urgent manner to ensure that the unification was as smooth as possible. In practice it became apparent that the allocated time was not sufficient, and the transition period was extended in some areas. The Article presents a review of the accession procedure and the legal regulations established in the Republic of Crimea during the transition period, and identifies some issues which have arisen.

Keywords: Russian legal system, Republic of Crimea, "accession”

Natalia Cwicinskaja, Adam Mickiewicz University Poznań, Faculty of Law and Administration, A1. Niepodległości 53,61-714 Poznań, e-mail: natalia.cwicinkaja@amu. edu.pl. 